\title{
Was Spain Different? Spanish Historical Backwardness Revisited*
}

\author{
César Molinas
}

Ministerio de Economia y Hacienda and Universidad de Barcelona

AND

\section{Leandro Prados de la Escosura}

Universidad de Alcala

In this paper we analyze the Spanish economic backwardness in a historical perspective. Following Chenery and Syrquin's methodology we discuss Spain's backwardness by comparing its development with a European norm. We conclude that Spanish structural change lagged behind improvements in per capita income. The Spanish experience could be described as a retarded one, although Spain did not fit a Third World or a Latin pattern. (c) 1989 Academic Press, Inc.

\section{INTRODUCTION}

Economic history of European nations has been written since World War II as a compromise between the traditional case study approach and the attempt to use generalizations, chiefly derived from models of economic development. On the one hand, dissatisfaction with isolated, national conceptions of economic growth led in the 1950 s and -60 s to the construction of general patterns of development through the use of economic models (see, for instance, Landes (1969)). On the other hand, after two decades of intense use of these patterns, historians started perceiving them as inadequate to explain the complex processes and the rich variety of experiences of economic development which took place

* We gratefully acknowledge financial support by FIES. We have received useful comments from A. Carreras, J. M. Esteban, A. Maddison, A. Mas-Colell, D. N. McCloskey, A. S. Milward, L. Neal, P. K. O'Brien, P. Tedde, G. Tortella, J. Viñals, and V. Zamagni, and participants at Banco de España's seminar, the 26th Cliometrics Conference and Universidad de Alcalá's Conference on "Growth and Structural Change in Italy and Spain: Historical Trends". Errors are our sole responsibility. 
in Europe in the 19th and early 20th century (see, for instance, Milward and Saul (1977)).

Despite this reaction, it seems clear that many important features of development can be studied only on a comparative basis. Realization of this underlies the European focus in the analysis of individual cases of economic growth as diverse as those by Pollard (1973, 1981), Crafts (1984), Cameron (1985), and O'Brien (1986) (but see, however, Good (1986)). The ideas expressed by concepts such as backwardness, retardation, or failure make sense only within a general framework which provides a method of analyzing differences and similarities (the remarkable redundancy in the much used expression "relative backwardness" is a good illustration of this fact).

In this paper we analyze the "Spanish historical backwardness" in the light of the available quantitative evidence. Following Chenery and Syrquin (1975) we think of development as a multidimensional transition from one relatively stable economic structure to another, occurring with a sufficient number of "common facts" across countries to originate recognizable and quantifiable patterns of accumulation, resource allocation, and demographic transition as real income per capita grows. We discuss Spanish backwardness by contrasting Spanish development with a "typical" European one, in the context of an analytical framework that allows us to give precise meanings to concepts such as "Europe" or "backwardness," concepts which are too frequently used in a loose fashion. This illuminates the possible causes of Spanish retardation and specifies the agenda for future research in quantitative Spanish economic history.

The rest of the paper is organized as follows. In Section II we introduce the "Spanish historical backwardness" problem, as well as the principal streams of thought relevant to it. Section III is devoted to the construction of the formal framework into which our analysis will proceed. Spanish backwardness with respect to Europe is analyzed in detail in Section IV. Section V contains conclusions and comments. The Appendix contains the discussion of the sources of statistical information we have used, as well as some additional data which form the basis of the analysis of Section IV.

\section{THE SPANISH HISTORICAL BACKWARDNESS: A FIRST GLANCE}

We look, first, at the Spanish backwardness problem from the point of view of real per capita income. This falls short of our final goal, which is to discuss the issue in a more elaborate framework, well illustrated by Kuznets' (1966) definition of modern economic growth-or development-as sustained increases in real product per capita accompanied by structural change. This starting point, however, is useful to set the problem and to make clear the need for a detailed analysis of the structural change. 
TABLE 1

Real per Capita Income in Western European Countries (1800-1930)

\begin{tabular}{|c|c|c|c|c|c|c|c|}
\hline & \multicolumn{3}{|c|}{$\begin{array}{c}\text { (1) } \\
\text { Spain }\end{array}$} & \multirow{2}{*}{$\begin{array}{c}\text { (2) } \\
\text { Britain }\end{array}$} & \multirow{2}{*}{$\begin{array}{l}\text { (3) } \\
\text { France }\end{array}$} & \multirow{2}{*}{$\begin{array}{c}\text { (4) } \\
\text { Germany }\end{array}$} & \multirow{2}{*}{$\begin{array}{l}\text { (5) } \\
\text { Italy }\end{array}$} \\
\hline & YPA & YMA & YCA & & & & \\
\hline \multicolumn{8}{|c|}{ I. \$ USA 1970} \\
\hline 1800 & 301 & & & 442 & 338 & - & - \\
\hline 1830 & (295) & 342 & - & 516 & 381 & 359 & 379 \\
\hline 1860 & 328 & 375 & 398 & 808 & 560 & 463 & 490 \\
\hline 1890 & 510 & 505 & 494 & 1136 & 745 & 648 & 495 \\
\hline 1910 & 585 & 610 & 667 & 1308 & 990 & 909 & 660 \\
\hline \multirow[t]{2}{*}{1930} & 798 & 798 & 798 & 1466 & 1337 & 1097 & 766 \\
\hline & & (1) & & (2) & (3) & (4) & (5) \\
\hline \multicolumn{8}{|c|}{ II. Britain $=100$} \\
\hline 1800 & & 68 & & 100 & 76 & - & - \\
\hline 1830 & & $57-66$ & & 100 & 74 & 70 & 74 \\
\hline 1860 & & $41-49$ & & 100 & 69 & 57 & 61 \\
\hline 1890 & & $44-45$ & & 100 & 66 & 57 & 44 \\
\hline 1910 & & $45-51$ & & 100 & 76 & 70 & 51 \\
\hline 1930 & & 54 & & 100 & 91 & 75 & 52 \\
\hline
\end{tabular}

Sources. 1950 Real GDP per head level in 1970 US\$ (purchasing power parities) from Summers, Kravis, and Heston (1980) projected backward with growth rates taken from Appendix, for Spain; Maddison (1982), for Britain, France, and Germany, from 1830; Crafts (1985) and Markovitch (1966) for Britain and France in 1800. For Italy, Ercolani (1978) and Bairoch (1976) for 1830.

Table 1 presents the evidence of a widening gap in real per capita income between Spain and Italy, on the one hand, and Great Britain, France, and Germany, on the other. ${ }^{1}$ Irrespective of which estimate of Spanish income is taken, real per capita income grew in Spain through the last half of the 19th century at roughly the same rate as in Britain and slightly faster in the first decades of the 20th century. Despite this growth, however, the differential of absolute levels of per capita income between Spain with the northwestern European countries became larger and larger, constituting the first basis of empirical evidence for the backwardness of 19th- and early 20th-century Spain with respect to the industrialized countries.

Two features of the growth processes summarized in Table 1 deserve comment. First, all countries shown had widening differentials with respect to Britain in the last half of the 19th century, with France and Germany closing the gap in the early 20th century. This indicates that increasing differences in real per capita income from a leading country are not a

\footnotetext{
${ }^{1}$ See Appendix for sources and details of the construction of the figures of Table 1.
} 
sufficient condition to identify backwardness, unless, of course, some kind of threshold is defined, but this seems to be a rather difficult thing to do. The second feature is that Spain compares well with Italy, maintaining similar levels of per capita income throughout the period. This is, at first sight, surprising, if one believes the literature (see, for instance, Vaccaro (1980) according to which Italy entered the 20th century having attained a much higher level of development than Spain). But this is to be set against structural change: the increase in income is an important indicator of the modernization process of a given country, but not always the crucial one.

Although formal discussions comparing Spain with other countries in quantitative terms are very rare in the vast literature about the Spanish backwardness, ${ }^{2}$ the main implication of Table 1 -the widening differential gap-has been widely perceived. The search for causes of the retardation has been one of the main concerns of scholars dealing with 19th- and 20th-century Spain. Historians seem to agree on the early picture drawn by Vicens Vives $(1959$, p. 7$)$ :

\begin{abstract}
Impoverished by internal wars, the selfishness of her ruling class and the backwardness of her masses, Spain achieved only an underdeveloped stage of capitalism during the 19th century.
\end{abstract}

There is also a general agreement that this sad state of affairs came as a result of a "failure" ${ }_{3}$ (Sanchez-Albornoz, 1968; Tortella, 1972, 1973; Nadal, 1973, 1975). Opinions are far less unanimous, however, about the kind of development which Spain had when entering the 20th century. Nadal $(1973,1975)$ has put forward the peculiar structure of "thwarted firstcomer" as opposed to the latecomers to economic development. Tortella and Prados (1984) point out a possible Latin pattern of European development which could accommodate the Spanish and Italian cases. Causes of the Spanish retardation have been located in almost every possible economic sector. Emphasis on the constraints for industrialization derived from low levels of income, whose roots are to be found in a high share of labor force engaged in low-productivity agriculture is put by Nadal (1973, 1975, 1984), Milward and Saul (1977), Tortella (1981, 1985a, 1985b), and Tortella and Prados (1984). Structural weaknesses of the industrial sector have been pointed out, among others, by Prados $(1983,1986)$ and Sanchez-Albornoz (1968) who stress the lack of dynamism and the import-substitution nature of Catalan cotton textiles; by Tortella (1981), who discusses the choice by Spanish entrepreneurs of strong

\footnotetext{
${ }^{2}$ Exceptions are Prados (1984) and Tortella and Prados (1984).

${ }^{3}$ Most authors would agree on the O'Brien and Keyder (1978) definition of failure as "opportunities missed, leads lost and output forgone because of neglect of best economic practice" (p. 15).
} 
protection, through rent-seeking attitudes against competition in the international markets; and by Fraile $(1985 \mathrm{a}, 1985 \mathrm{~b})$ who suggests lower growth elasticities for cotton and iron and steel Spanish industries as compared to other peripheral nations in 19th-century Europe. Government policies' share of guilt in economic retardation through the "crowding out" effect of its chronic budget deficits is stressed by Tortella (1972, 1973, 1981, 1985a, 1985b), Nadal (1973, 1975), and Pollard (1981). The effect of the loss of the colonial empire has been cited by Milward and Saul (1977), Pollard (1981), and Berend and Ranki (1982) (but, for revisionist views see Anes (1983), and Prados (1982b, 1986)). The role of foreign trade has been frequently analyzed also (Sanchez-Albornoz, 1968; Nadal, 1973, 1975; Fraile, 1985a; Harrison, 1978; Prados, 1982a, 1986). Pollard (1973), Berend and Ranki (1982), Trebilcock (1981), and Harrison (1978) suggest a semi-colonial position for Spain within the European framework.

\section{THE ANALYTICAL FRAMEWORK}

Backwardness is of course relative, its very idea implying the existence of some benchmark that allows for comparisons. Implicitly, all statements about the "Spanish relative backwardness" assume the existence of a norm or pattern of development through European industrial revolution in the 19th century, the separation of Spain from the norm being called "backwardness." The implicit European pattern has always been vague, and not seldom lacking a sound historical basis.

In this section we give a precise definition of what we call the European norm. Following Chenery and Syrquin (1975) and Crafts (1984) we select a set of variables which are representative of development. ${ }^{4}$ These variables are listed in Table 2. The European norm is, then, a mathematical model of determination of these variables as functions of per capita income and population levels. More precisely,

$$
\mathbf{d}=E \mathbf{s},
$$

where $\mathbf{d}$ is a vector containing the 10 dependent variables, $\mathbf{s}$ is a vector whose elements are per capita income and population level, and $E$ is a $(10 \times 2)$ matrix of fixed coefficients. We stick to the usual rationale for Eqs. (1), thinking of them as a subset of the reduced form of a, possibly very large, general equilibrium system in which per capita income and population levels are the ultimate exogenous variables. History is embedded in the model by means of the choice of the matrix $E$.

Crafts (1984) has estimated these coefficients by regression methods from a pooled sample of decennial observations of 17 European countries

4 Data availability, as well as the need to comply with Crafts' (1984) model, has compelled us to take a subset of the variables considered by Chenery and Syrquin (1975). 
TABLE 2

Patterns of Development in Spain and Italy

\begin{tabular}{lcccc}
\hline Year: & 1860 & 1890 & 1910 & 1930 \\
\hline Population Spain & 15.7 & 17.7 & 19.9 & 23.4 \\
Per capita income Spain & $328-398$ & $494-510$ & $585-667$ & 798 \\
Population Italy & 25.0 & 30.5 & 34.7 & 41.2 \\
Per capita income Italy & 490 & 495 & 660 & 766
\end{tabular}

I. Accumulation process

1. Domestic investment [percentage of Gross National Product (GNP)]

$\begin{array}{lcccc}\text { Spain } & 5.3 & 6.9 & 8.2 & 13.5 \\ \text { "European Spain" } & 11-12 & 14 & 15-16 & 16.7 \\ \text { Italy } & 5.8 & 9.2 & 17.2 & 15.4 \\ \text { "European Italy" } & 13.6 & 13.7 & 15.5 & 14.4\end{array}$

2. School enrollment (percentage of population aged 5-19 enrolled in primary education)

$\begin{array}{llrll}\text { Spain } & 27.1 & - & 30.6 & 32.9 \\ \text { "European Spain" } & 21-26 & - & 39-42 & 47.9 \\ \text { Italy } & 16.0 & 28.5 & 34.2 & 43.6 \\ \text { "European Italy" } & 32.7 & 33.1 & 42.0 & 46.6\end{array}$

3. Structure of Demand

II. Resource Allocation Processes

a. Private consumption (percentage of GNP)

\begin{tabular}{lllll} 
Spain & 90.5 & 87.8 & 83.7 & 78.3 \\
"European Spain" & $81-82$ & 79 & $77-78$ & 76.0 \\
Italy & 88.9 & 84.5 & 80.9 & 75.5 \\
"European Italy", & 79.6 & 79.4 & 77.4 & 76.2 \\
\multicolumn{2}{l}{ b. Government consumption (percentage of GNP) } & & \\
Spain & 8.7 & 8.2 & 6.5 & 8.3 \\
"European Spain", & $7-8$ & 7 & 7 & 6.4 \\
Italy & 8.4 & 7.2 & 7.4 & 11.0 \\
"European Italy" & 7.2 & 7.2 & 6.7 & 6.5
\end{tabular}

4. Structure of production

a. Primary share (percentage of primary sector in GNP)

$\begin{array}{lllll}\text { Spain } & 39.6 & 39.3 & 37.7 & 32.8 \\ \text { "European Spain" } & 47-51 & 39-41 & 33-36 & 28.3 \\ \text { Italy } & 46.1 & 42.5 & 37.0 & 30.3 \\ \text { "European Italy", } & 41.2 & 40.9 & 33.3 & 29.3 \\ \text { b. Industry share (percentage of secondary sector in GNP) } & & \\ \text { Spain } & 17.9 & 20.5 & 21.6 & 22.1 \\ \text { "European Spain" } & 20-22 & 24-25 & 26-28 & 30.0 \\ \text { Italy } & 18.4 & 20.8 & 25.7 & 29.7 \\ \text { "European Italy" } & 24.1 & 24.4 & 27.7 & 29.6 \\ \text { 5. Structure of trade } & & & & \\ \quad \text { a. Exports (percentage of GNP) } & & & \\ \text { Spain } & 4.6 & 13.4 & 11.8 & 7.7 \\ \text { "European Spain" } & 6-9 & 12 & 14-16 & 18.0\end{array}$


TABLE 2

Patterns of Development in Spain and Italy

\begin{tabular}{lrcrr}
\hline Year: & 1860 & 1890 & 1910 & 1930 \\
\hline Italy & 6.0 & 7.0 & 9.2 & 8.6 \\
"European Italy" & 10.4 & 9.9 & 14.0 & 15.8
\end{tabular}

6. Labor allocation

a. Primary share (percentage of labor force in primary sector)

\begin{tabular}{lllll} 
Spain & 63.5 & 64.7 & 66.0 & 45.5 \\
"European Spain" & $66-71$ & $57-60$ & $51-54$ & 45.8 \\
Italy & 69.7 & - & 59.1 & 54.4 \\
"European Italy" & 59.4 & - & 51.1 & 47.0 \\
7. Demographic transition & & & & \\
a. Crude birth rate (births per thousand inhabitants) & & \\
Spain & 36.7 & 34.4 & 32.7 & 27.9 \\
"European Spain", & $37-39$ & $35-36$ & $34-35$ & 32.5 \\
Italy & 37.4 & 34.2 & 27.2 & 23.0 \\
"European Italy" & 35.7 & 35.9 & 33.8 & 32.9 \\
b. Crude death rate (deaths per thousand inhabitants) & & \\
Spain & 27.4 & 32.1 & 23.1 & 17.1 \\
"European Spain", & $27-29$ & $25-26$ & $24-25$ & 22.7 \\
Italy & 30.3 & 23.7 & 21.8 & 13.9 \\
"European Italy", & 25.8 & 26.1 & 23.9 & 23.0 \\
\hline
\end{tabular}

within the 19th century. ${ }^{5}$ His equations seem to fit reasonably well and provide a basis for claiming the existence of a common pattern of development. ${ }^{6}$ The peculiarities of the sample suggest that the estimate of $E$ is somewhat biased toward the more developed countries: the less developed countries provide fewer observations because of lack of data, and Russia is the only country from Eastern Europe which is considered. The effect is amplified, of course, by the downward bias of Crafts' estimation of European countries' income, but the inclusion of dummy variables in the equations compensates for part of the expected bias. ${ }^{7}$ In any case, there appears no disadvantage in this for the purpose of the following analysis.

Our matrix $E$ consists of Crafts' estimates together with our estimates

\footnotetext{
${ }^{5}$ Two observations correspond to the 18th century and 17 to 1910 . We have not tried, in this paper, to improve on Crafts' estimation method or in the functional form of his equations, although we feel that the statistical insignificance of the quadratic terms in income and population is not a sufficient reason to dismiss their use: the proportional effects implied by linearity may prove inconvenient in modeling some actual processes.

${ }^{6}$ Most $R^{2}$ lie between 0.6 and 0.8 , although those of the equations for Private Consumption and Investment are barely higher than $\mathbf{0 . 4}$.

${ }^{7}$ See Appendix for a discussion of this bias.
} 
for the export equation. ${ }^{8}$ With that choice of $E$ the European norm can be thought of as being "the" typical European country in the sense that, for arbitrary levels of population and per capita income, it produces values of the vector of dependent variables-the pattern of developmentthat are typical in European development for a country of this size. In other words, the norm is a simulated Spain with European characteristics. Comparisons of Spain with the European norm are straightforward. For every historical value of the Spanish population and income, we can simulate the values of the vector of dependent variables for the norm and take differences with the actual values of the corresponding Spanish variables. Small differences imply a "European" kind of process while large differences imply "backwardness." The norm is a heuristic device to highlight the main features of Spanish development, in particular those that clearly diverge from Western Europe and make Spain unique. It should be noted that the norm always has the same population level and per capita income as Spain but, by its construction, is completely atemporal and therefore the simulated values of the dependent variables cannot be located in any historical time or place within 19th-century Western Europe.

In Table 2 we present the actual values of the 10 dependent variables for Spain from 1850-1930 and the simulated values following the European norm.

\section{SPANISH HISTORICAL BACKWARDNESS: A DISCUSSION}

In this section we discuss the Spanish backwardness from the point of view of the structural change that accompanies the increases of real per capita income in modern economic growth. The discussion will proceed along the lines set up by the variables listed in Table 2 which we take to represent the "stylized facts" that are at the core of the development process of any country. Our goal is to determine whether the Spanish structural change has converged to or diverged from the European one, as defined by the European norm.

We have taken the series YCA, YMA and YPA as the best estimates of Spanish real per capita income during the considered period 18501930 (See Appendix for a more complete discussion). The main results, however, are robust with respect to any particular selection of the estimate income. We discuss this issue at the end of the section.

\section{Accumulation Process}

Following Chenery and Syrquin (1975) we think of accumulation as "the use of resources to increase the productive capacity of an economy"

${ }^{8}$ The estimated exports equation follows the Chenery and Syrquin functional form:

$$
\operatorname{EXP}=-\underset{(5.9)}{7}\left(\begin{array}{l}
7.1) \\
15.4
\end{array} \text { LOG }(\mathrm{PCI})-\underset{(5.8)}{2.9} \mathrm{LOG}(\mathrm{POP}) ; R^{2}=0.67 ; \mathrm{D} . \mathrm{W} .=1.2\right.
$$


(p. 23). We examine here investment and schooling rate, as measures of increases in stock.

As shown in Table 2, Spanish rates of investment are very low when compared to the European norm. Although there is a slow process of convergence to Europe, investment remains well below European rates throughout the period under study. This fact suggests a "residual" character of investment in the allocation of expenditure and is worthy of future historical research.

The most popular explanation for the low Spanish investment rate has been the "crowding out" of private investment by the government financing its budget deficits through the issue of debt' $^{9}$ (see Tortella, 1972, 1973, 1985b; Nadal, 1973, 1975, 1984; and Tortella and Prados, 1984). Unfortunately, only scanty information on interest rates is available (see Tortella (1973)) but there is both quantitative and qualitative evidence on government financial difficulties which led to considerable debt issuing since the loss of the colonial empire (Fontana, 1970; Tortella, 1973). The systematic resort to public debt led to a rising in its cost up to $30-45 \%$ of public expenditure, or $4 \%$ of GNP, from 1880 to 1900 (Tedde, 1985) while the budget deficit represented $1 \%$ of GNP in a period in which government revenue fluctuated around $10 \%$ of GNP, a figure below that of France and Italy in the same period (Tedde, 1985).

Although there is a convergence to the European norm, Spanish demand for investment remained chronically small, casting doubt on the "crowding out" hypothesis as the only explanation-or even the main one-for the low levels of investment. Quite the contrary, the weak demand for investment, jointly with its "residual" character, probably has deep roots.

Accumulation of human capital is an important aspect of capital formation. Although Spanish statistics in schooling rates are shaky, figures from Table 2 show an unmistakable process of divergence from Europe. Taking into account the existence of a clear time trend in historical series of school enrollment (see, for instance, Chenery and Syrquin (1975), p. 26) and that some actual European countries attained Spanish historical income levels at earlier dates-when government concern for education was less marked-we must conclude that the divergence should be stressed; this is, of course, a side effect of the atemporality of the norm, but it can be easily controlled for. The lack of public concern about education in Spain is supported by the slow growth of schooling rates, below those of population and per capita income, confirming historiographical claims (Tortella, 1981; Tortella and Prados, 1984; Cameron, 1985).

To conclude, Spanish accumulation did not converge to the European norm. Physical capital formation started the period at a very low level,

9 See Williamson (1984, 1987) and Heim and Mirowski (1987) for a general discussion and a case study of Britain. 
and nothing suggests a "catching up." The gap in human capital formation clearly tended to widen as per capita income increased, in open divergence from the norm.

\section{Resource Allocation}

As per capita income increases, consumption is expected to decline in relative terms, while changes in factor proportions and technological improvements, derived from increasing capital formation, influence the composition of the product mix. Comparative advantage and natural endowments also determine the structure of production.

Spanish private consumption shows a declining trend, in relative terms, and a clear convergence to the European norm. Levels of private consumption, however, are always higher in the actual Spain than in the counterfactual European Spain. This suggests an irreversible pattern of consumption and implies less sacrifice of current consumption in order to increase future consumption than European standards, i.e., lower investment levels. Real private consumption per head shows a constant improvement (growing at an average $1 \%$ a year), proviiding a more optimistic picture of material welfare than the prevailing one. Lack of information on income and wealth distribution however makes it difficult to be more positive.

The evolution of public consumption does not have a clear trend. There are no dramatic disparities between the Spanish structure of demand and the one implied by the European norm. Both private and total consumption tended to close the gap as income rose. Historical explanations can be provided for the Spanish government's behavior: higher investment rates and indirect government interventions, such as subsidies to railway construction (Tortella, 1972, 1973), account for the high levels of mid-19th century, while interventionist policies account for the high levels of 1920 and 1930 (see Palafox (1980) but also Comin and Martin Aceña (1984)).

The Spanish primary sector's share in production diverged from the European norm. Spanish agriculture accounted for a smaller share at levels of income below $\$ 500$ and reversed the pattern afterward. The response to the foreign threat to agriculture after 1880 , due to the transportation revolution, was a strong protectionism that led to a reinforcement of traditional agriculture (García-Lombardero, 1985; GEHR, 1983, 1985), keeping resources tied to the land despite a considerable productivity differential between agrarian and nonagrarian activities. The costs for economic modernization of Spain caused by such a misallocation of resources deserve further exploration.

There is not a convergent trend in the differentials of the industrial sector's share in production. An attempt to reduce the gap took place somehow although Spanish industry's share in total output remained lower than in Europe at all income levels except $\$ 800$. Industrial growth 
took place almost exclusively on the basis of the home market (see Prados (1988)), exports representing less than $7 \%$ of total manufacturing production by 1930 . Strong and persistent protectionism seems to be at the roots of the poor performance of Spanish industry in the international sector, particularly during the phase of acceleration of industrialization in the interwar period.

The evidence available on the structure of trade shows that after a convergent trend within the $\$ 300-\$ 500$ income range, Spain developed a substantially smaller weight of the foreign sector compared with Europe, at income levels above $\$ 500$.

Further, most Spanish exports were foodstuffs and raw materials which suggests that the role of foreign trade in developing a modern industrial sector was considerably smaller in Spain than in Europe. This supports the image of a not very efficient industrial sector expanding behind a high tariff barrier and choosing rent-seeking as an alternative to competition (Fraile, 1985a; Prados, 1988) but contrasts with Nadal (1973, 1975). Foreign trade represented a smaller fraction of national income than is implicit in current historiography. (Prados, 1982a). This does not preclude that it played a dynamic role prior to the $1890 \mathrm{~s}$, despite the constraints imposed by its small weight. In that period foreign trade grew at a rate triple that of GNP and helped to enlarge a growing market, stimulated the use of otherwise idle resources, promoted transportation improvements, induced the creation of metal processing industries in mining areas, and helped in the emergence of a financial system (Prados, 1982a).

\section{Demographic and Distributional Processes}

In developing countries, the frontier between agrarian and nonagrarian activities is not clear-cut, implying an upward bias in statistics of employment in the primary sector (cf. Pérez Moreda, 1984, 1985; Caron, 1979; Crafts, 1984). Since this is a problem common to most European countries at the considered income levels, biases will tend to be systematic and results from comparisons between Spain and the European norm will not be greatly affected.

The percentage of active population employed in the primary sector in Spain tends to remain unchanged in the considered period. ${ }^{10}$ As a consequence, differentials with Europe grew until 1910. Afterward the share in actual Spain began to converge with the European norm.

The picture that emerges from the evidence is one of stagnation in the sectorial allocation of labor that contrasts with the sustained growth of real product per head. An explanation for this apparent contradiction would be the shift of manpower from lower to higher productivity activities

\footnotetext{
${ }^{10}$ Pérez Moreda's estimates suggest that a similar proportion would stand for lower income levels $(\$ 300)$ corresponding to the early 19th century.
} 
within the primary sector and the reduction of disguised unemployment and redundant labor. The effects of disentailment-through rising demand for labor-and changes in relative prices favorable to traditional products, as an effect of the strong protectionist measures of 1891 and 1906, may also be plausible causes of the high share of labor involved in primary production. A dramatic fall took place, however, after 1910, the share being reduced from two-thirds to less than half of total active population.

The caveats made in the schooling rate case about the atemporality of the norm apply to the birth and death rates also. The linearity of Eqs. (1) is, probably, responsible for the rather implausible population levels implied by the norm (see Crafts (1984), p. 446). Within the model, population pressure tends to be milder for Spain than for Europe, since birth rates tend to be lower and mortality higher. Differences with the European norm show a widening gap for the birth rate and a somewhat narrowing gap for the death rate. As already stated, this is not a very plausible picture.

Demographic transition lagged in Spain, though it took place eventually within the limits of a European pattern. Suggestions that slow population growth was a result of poor economic performance, since it derived from high mortality rates, (Nadal, 1973, 1975; Tortella, 1981, 1985a; Perez Moreda, 1984), are supported by the comparison with the European norm at income levels below $\$ 600$.

\section{CONCLUSIONS}

We have defined backwardness as a widening gap in real per capita income with respect to the more advanced countries, accompanied by a divergence in structural change from the European norm. The analysis concludes that a lagged and slow process of modernization took place in Spain and provides grounds for describing the Spanish experience as a retarded one. But Spain did not develop as a current Third World country. ${ }^{11}$ Nor is there a Latin pattern of development.

Since both Spain and Italy attained similar levels of income of roughly the same historical dates, the idea of a Latin, Mediterranean, or Southern European pattern of development is a plausible one, and though recently formulated (Tortella and Prados, 1984) has been in the back of historians' minds for a long time. We have done a comparison of structural transformation between Italy and the European norm in the same way we did it for Spain in Section IV. The numerical results appear also in Table 2.

\footnotetext{
"The Chenery and Syrquin equations can be used to adopt a "Third World" pattern which captures the characteristics of development of the latecomers to industrialization. We have compared Spain with that norm and concluded that the divergence of Spain from Europe is not explained by any approach to a Third world pattern.
} 
Accumulation processes appear to be more European in the Italian case than in the Spanish one. The contrast between Italian investment and its Spanish counterpart is remarkable: Italian investment converges to European standards at a rate that roughly trebles the Spanish one. Human capital formation, as measured by schooling rates, follows an opposite condition: Italy closes the gap with Europe while the contrary happens in Spain.

As far as resource allocation is concerned, Italian structure of demand, although closer to the norm, is not strikingly dissimilar to the Spanish one. Trade structure reveals for Italy as for Spain (though more markedly for the latter) a lower degree of openness than the one implied by the European norm at any income level.

Despite the primary share larger than and the industry share smaller than the European norm at any considered income level, the Italian structure of production clearly converged with the European one.

Despite common features, such as reaching similar levels of real per capita income at approximately the same dates, Spain and Italy have structural change processes that do not fit a common pattern: Spain diverges from the European norm; Italy converges to it.

The idea of two different ways to economic growth is more convincing than the Latin pattern: while in Italy structural changes were deep and tended to occur at the same time as per capita income grew, in Spain structural transformations lagged far behind improvements in average incomes.

Weak investment demand, the persistence of a large traditional agrarian sector, and poor industrial performance tend to confirm the view of Spanish economy prior to its Civil War in the 1930s as retarded, isolated, with a poor agriculture and a low degree of industrialization, but starting, nevertheless, modern economic growth. Paradoxically, Spain appears to have achieved standards of per capita income caparable to those of Italy, a country which experienced a more profound-and European-transformation. Spain followed her own, different way to modernization.

\section{APPENDIX}

\section{Sources of Empirical Information}

\section{Income Levels at 1970 U.S. Dollars}

We have preferred the use of the Purchasing Power Parity System (PPP) to the more oftenly used of exchange rates (see Eichengreen (1986) for a discussion). Use of PPP has been made by Crafts $(1983,1984)$ on the basis of the Kravis et al. (1978) estimates of 1970 levels of per capita product in 1970 U.S. dollars. Crafts has extrapolated them backward to 1910 adopting Bairoch's growth rates for real product per head between 1910 and 1970, and backward again through the 19th century. Our method 
differs from Crafts' in that we have chosen the more recent Summers et al. (1980) estimates in 1970 U.S. dollars, which provide levels of real per capita income for 1950 and, on this basis, we have built the series from 1800 to 1930 . Also, we have used more recent estimates for the GNP of Italy (Ercolani, 1978); Britain, France, and Germany (Maddison, 1982); and Spain (Alcaide, 1976; Carreras, 1985; Prados, 1988).

Our estimates suggest that Crafts underestimated levels of real per capita income for 1910 in the Italian and Spanish cases, and a similar conclusion can be derived for Belgium, Austria, Sweden, and Finland, implying that the bias of the European norm toward early developers, given by the unequal number of observations, is further amplified. Happily, this is an advantage for the purpose of this paper, since it allows the comparison of Spain to a norm that is more representative of the "early comers" to development than of the average of European countries.

Crafts' resort to the Beckerman and Bacon (1966) indirect techniques for the estimation of levels of per capita income in Spain gives an idea of the problems posed by the scarcity of national accounting estimates for 19th-century Spain. Prados (1982a) has recalculated Mulhall's estimates for 19th-century Spain's income following Deane's (1957) advice. Linking Mulhall-Prados estimates for 1830-1890 with Alcaide's (1976) revision of CEN (1965) figures, we obtained the series YMA.

Carreras (1985) has attempted an ambitious project: to provide an index number series for Gross National Expenditure from 1849 to 1958. Some indirect tests of Carreras' series show that this series seem to be more reliable from 1900 to 1935 than its competing counterparts. However, when linked to the 1950 level of real per head product as given by Summers et al. (1980), Carreras' series produces implausibly high income levels for 1910. Our solution has been to accept Carreras series for 1860 1930 linking it with Alcaide's per capita income level for 1930. The resulting series is YCA.

Alternatively, Prados (1988) has built up benchmark estimates for real GDP per head from 1800 to 1930 . Real GDP derives from weighting quantity indices for output in agriculture, industry, and services with Vandellós' (1925) estimates of sectorial shares in GDP for 1913. Prados' estimates for 1800-1930 have been linked to the 1950 level of real GDP per head in 1970 U.S. dollars with Alcaide's (1976) growth rate for Spain's real product per capita between 1930 and 1950 . The resulting series is YPA.

Our results depend, obviously, on the whole set of data we have used. If one variable should be singled out for its crucial role, however, it would be Spanish per capita income. Alternative specifications of the series generate different values for all variables in the European norm. (Spanish observed values of the same variables are not, of course, affected.) Given the shaky character of all estimates of this magnitude, it is natural 
to ask how sensitive are our results to the selection of the series YCA and YPA as our estimates of Spanish income.

This is a ceteris paribus kind of question, and in order to get an answer, we have done the whole analysis of this section using series YCA, YMA, and YPA. While the series YCA is likely to be an upper bound for all plausible estimates of Spanish income, the series YPA plays a role of a lower bound. The expected global effect of lowering the estimate of income is a more "European" picture of Spain when compared to the norm, because of the bias of the latter toward the more advanced countries. This was not the case, as the main consequences of the analysis performed with YCA remain unchanged when YMA or YPA are adopted. Therefore the divergent picture drawn in this section is very robust with respect to any estimate of Spanish income falling within the range between YPA and YCA which appears to be the relevant one.

\section{Other Sources}

1. Domestic Investment: Spain, Carreras (1985); Italy, Ercolani (1978).

2. School Enrollment: Spain and Italy, Mitchell (1975).

3. Private and Public Consumption: Spain, Carreras (1985); Italy, Ercolani (1978).

4. Structure of Production: Spain, Prados (1988); Italy, Ercolani (1978).

5. Structure of Trade: Spain, Prados (1988). Italy, Mitchell (1975), Ercolani (1978).

6. Labor Allocation: Spain, Pérez Moreda (1984); Italy, del Panta (1979).

7. Demographic Transition: Spain, Mitchell (1975); Italy, del Panta (1979).

\section{REFERENCES}

Alcaide, J. (1976), “La renta nacional 1901-1970: una revisión urgente." In M. de Hacienda (Ed.), Datos para la Historia Financiera de España. Madrid: Instituto de Estudios Fiscales.

Anes, G. (1983), "La agricultura española y las colonias americanas." In G. Anes, L. A. Rojo, and P. Tedde, (Eds.), Historia Económica y Pensamiento Social. Madrid: Alianza Ed.-Banco de España. Pp. 193-204.

Bairoch, P. (1976), Commerce extèrieur et développment économique de l'Europe au XIX siècle. Paris: Mouton.

Beckerman, W., and Bacon, R. (1966), "Internacional Comparisons of Income Levels: a Suggested New Measure." Economic Journal 76, 619-636.

Berend, I. T., and Ranki, G. (1982), The European Periphery and Industrialization 17801914. Cambridge: Cambridge Univ. Press.

Cameron, R. (1985), "A New View of European Industrialization." Economic History Review 38, 1-23.

Caron, F. (1979), An Economic History of Modern France. London: Methuen. 
Carre, J. J., Dubois, P., and Malinvaud, E. (1975), French Economic Growth. Oxford: Oxford Univ. Press.

Carreras, A. (1984), "Un nuevo índice de la producción industrial española: 1849-1958." Revista de Historia Económica II 1, 127-157.

Carreras, A. (1985), "Gasto Nacional Bruto y Formación de Capital en España, 18491958." In P. Martín Aceña and L. Prados de la Escosura (Eds.), La Nueva Historia Económica en España. Madrid: Tecnos. Pp. 17-51.

Chenery, H., and Syrquin, M. (1975), Patterns of Development, 1950-1970. Oxford: Oxford Univ. Press.

Comin, F., and Martin Aceña, P. (1984), "La política mentaria y fiscal durante la Dictadura y la Segunda República." Papeles de Economía Española 20, 236-261.

Consejo de Economia Nacional (1965), La Renta Nacional de España. Madrid: Consejo de Economía Nacional.

Crafts, N. F. R. (1983), "Gross National Product in Europe 1870-1910: Some New Estimates." Explorations in Economic History 20, 387-401.

Crafts, N. F. R. (1984), "Patterns of Development in Nineteenth Century Europe." Oxford Economic Papers, 36, 438-458.

Crafts, N. F. R. (1985), British Economic Growth during the Industrial Revolution. London/New York: Oxford Univ. Press (Clarendon).

Deane, P. (1957), "Contemporary Estimates of National Income in the Second Half of the Nineteenth Century." Economic History Review 9, 451-461.

Eichengreen, B. (1986). "What Have We Learned from Historical Comparisons of Income and Productivity?" In P. O'Brien (Ed.), International Productivity Comparisons and Problems of Measurement, 1750-1939, 9th International Economic History Congress, Bern. Pp. 26-35.

Ercolani, P. (1978). "Documentazione Statistica di Base." In G. Fuá (Ed.), Lo Sviluppo economico in Italia. Milano: Franco Angeli. Vol. 3, pp. 388-472.

Fontana, J. (1970), La quiebra de la Monarquia absoluta, 1814-1820. Barcelona: Ariel.

Fraile, P. (1985a), "El Fracaso de la Revolución Industrial en España: un modelo cerrado de industrialización." Información Comercial Española, 623, 97-104.

Fraile, P. (1985b), "El Pais Vasco y el mercado mundial." In N. Sanchez-Albornoz (Ed.), La modernización económica de España (1830-1930). Madrid: Alianza. Pp. 226-252.

Garcia-Lombardero, J. (1985), "Los efectos de la protección arancelaria sobre la producción de cereales en España, 1890-1910." In Martín Aceña and Prados de la Escosura (Eds.) La Nueva Historia Económica en España. Madrid: Tecnos. Pp. 192-203.

GEHR (1983), "Notas sobre la producción agraria española, 1891-1931." Revista de Historia Económica, I 2, 185-252.

GEHR (1985), "Evolución de la superficie cultivada de cereales y leguminosas en España, 1885-1935". In Martin Aceña and Prados de la Escosula (Eds.), La Nueva Historia Económica en España. Madrid: Tecnos. Pp. 52-70.

Good, D. F. (1986), "Uneven Development in the Nineteenth Century. Comparison of the Habsburg Empire and the United States." Journal of Economic History 46, 137-151.

Harrison, J. (1978). An Economic History of Modern Spain. Manchester: Manchester Univ. Press.

Heim, C. E. and Mirowski, P. (1987). "Interest Rates and Crowding-out during Britain's Industrial Revolution." Journal of Economic History 47, 117-139.

Kravis, I. B., Heston, A. and Summers, R. (1978), "Real GDP Per Capita for More than One Hundred Countries." Economic Journal 88, 215-242.

Kuznets, S. (1966), Modern Economic Growth: Rate, Structure and Spread. New Haven, CT: Yale Univ. Press.

Kuznets, S. (1971), Economic Growth of Nations. Cambridge, MA: Harvard Univ. Press. Landes, D. (1969), The Unbound Prometheus. Technological Change and Industrial De- 
velopment in Western Europe from 1750 to the Present. Cambridge: Cambridge Univ. Press.

Maddison, A. (1982), Phases of Capitalist Development. Oxford: Oxford Univ. Press.

Markovitch, T. I. (1966), L'industrie française de 1789 à 1964. Cahiers de l'ISEA.

Martin Aceña, P. (1984), "España y el Patrón-Oro, 1880-1913." Hacienda Pública Española 69, 267-290.

Martin Aceña, P. (1985), "Déficit público y política monetaria en la Restauración, 18741923." In Martín Aceña and Prados de la Escosura (Eds.). La Nueva Historia Económica en España. Madrid: Tecnos. Pp. 262-284.

Milward, A. S. and Saul, S. B. (1977), The Development of the Economies of Continental Europe 1850-1914. London: Allen \& Unwin.

Mitchell, B. R. (1975), European Historical Statistics 1750-1970. London: MacMillan \& Co.

Nadal, J. (1973), "The Failure of the Industrial Revolution in Spain, 1830-1914." In C M. Cipolla (Ed.), The Fontana Economic History of Europe. Vol. 4, No. 2, pp. 532626.

Nadal, J. (1975), El Fracaso de la Revolución Industrial en España, 1814-1913. Barcelona: Ariel.

Nadal, J. (1984), “El Fracaso de la Revolución Industrial en España. Un balance historiográfico." Papeles de Economía Española 20, 108-125.

O'Brien, P. (1986), "Do we have a Typology for the Study of European Industrialization in the XIXth Century?." Journal of European Economic History 15(2), 291-333.

O'Brien, P., and Keyder, C. (1978), Economic Growth in Britain and France 1780-1914. London: Allen \& Unwin.

Palafox, J. (1980), "La Gran Depresión de los años 30 y la crisis industrial española." Investigaciones Económicas II, 5-46.

Panta, L. del (1979), “Italy.'” In W. R. Lee (Ed.), European Demography and Economic Growth. London: Croon Helm. Pp. 196-235.

Perez Moreda, V. (1984), "Evolución de la población española desde finales del Antiguo Régimen." Papeles de Economía Española 20, 20-38.

Perez Moreda, V. (1985), "La modernización demográfica, 1800-1930. Sus limitaciones y cronología." In Sánchez-Albornoz (Ed.), (1985), La modernización económica en España (1830-1930). Madrid: Alianza. Pp. 25-63.

Pollard, S. (1973), "Industrialization and the European Economy." Economic History Review 26, 636-648.

Pollard, S. (1981), Peaceful Conquest. The Industrialization of Europe, 1760-1970. Oxford: Oxford Univ. Press.

Prados de la Escosura, L. (1982a), Comercio exterior y crecimiento económico en España, 1826-1913. Tendencias a largo plazo. Madrid: Banco de España.

Prados de la Escosura, L. (1982b), "La independencia hispanoamericana y sus consecuencias económicas en España: una estimación provisional." Moneda y Crédito 163, 49-69.

Prados de la Escosura, L. (1983), "Producción y consumo de tejidos en España, 18001913: primeros resultados." In Anes, Rojo, and Tedde (Eds.), Historia Económica y Pensamiento Social. Madrid: Alianza. Pp. 455-471.

Prados de la Escosura, L. (1984), "El crecimiento económico moderno en España 1830 1973: una comparación internacional." Papeles de Economía Española 20, 151-155.

Prados de la Escosura, L. (1986), Quantitative Explorations into Spain's Economic Backwardness (1784-1913). Unpublished D. Phil. thesis, Oxford.

Prados de la Escosura, L. (1988), De Imperio a Nación. Crecimiento y atraso económico en España (1780-1930). Madrid: Alianza.

Sanchez-Albornoz, N. (1968), España hace un siglo: una economía dual. Barcelona: Península. 
Sanchez-Albornoz, N. (1981), "El consumo de textiles en España 1860-1890." Hacienda Pública Española 69, 229-235.

Sanchez-Albornoz, N. (Ed.). (1985), La modernización económica de España (1830-1930). Madrid: Alianza.

Summers, R., Kravis, I. B. and Heston, A. (1980), "International Comparisons of Real Product and its Composition: 1950-1977." Review of Income and Wealth 26, 19-66.

Tedde, P. (1985), "El gasto público en España, 1875-1906. Un análisis comparativo con las economías europeas." In Martín Aceña and Prados de la Escosura (Eds.). La Nueva Historia Económica en España. Madrid: Tecnos. Pp. 233-261.

Tena, A. (1985), "Una reconstrucción del comercio exterior español, 1914-1935: la rectificación de la estadísticas oficiales." Revista de Historia Económica, III 1, 77-119.

Tortella, G. (1972), "Spain 1829-1874." In R. Cameron (Ed.), Banking and Economic Development. Oxford: Oxford Univ. Press. Pp. 91-121.

Tortella, G. (1973), Los orígenes del capitalismo en España. Madrid: Tecnos.

Tortella, G. (1981), "La economía española, 1830-1900." In M. Tuñón de Lara (Ed.), Historia de España: Vol. VIII. Revolución burguesa, oligarquía y constitucionalismo. Barcelona: Labor. Vol. 7, pp. 9-167.

Tortella, G. (1985a), "Producción y productividad agraria en España, 1830-1930." In Sánchez-Albornoz (Ed.), La modernización económica en España (1830-1930). Madrid: Alianza. Pp. 63-88.

Tortella, G. (1985b), "La economía española a finales del siglo XIX y principios del siglo XX." In J. L. García Delgado (Ed.), La España de la Restauración. Madrid: Siglo XXI. Pp.133-151.

Tortella, G. and Prados, L. (1984), The Pattern of Economic Modernization in Southern Europe." (mimeo)

Trebilcock, C. (1981), The Industrialization of the Continental Powers 1780-1914. London: Longman.

Vaccaro, R. (1980), "Industrialization in Spain and Italy 1860-1914." Journal of European Economic History 9, 709-51.

Vandellos, J. A. (1925), "La richesse et le revenue de la péninsule ibérique." Metron, V 4, 151-186.

Vicens Vives, J. (1959), Manual de Historia Económica de España. Barcelona: Vicens Vives.

Williamson, J. G. (1984), "Why Was British Growth so Slow during the Industrial Revolution." Journal of Economic History 44, 687-712.

Williamson, J. G. (1987), "Has Crowding-out Really Been Given a Fair Test? A Comment." Journal of Economic History 47, 214-216. 